\author{
Can the Tropics Catch Up? Climate and Agriculture in Economic Growth \\ (William A. Masters, Purdue University, presiding)
}

\title{
Agriculture, Chimate, and Technology: Why Are the Tropics Falling Behind?
}

\author{
John Luke Gallup ANd Jeffrey D. Sachs
}

The tropics, sadly, continues to be a belt of poverty. The countries of the tropics all have low or middling incomes, with a few tiny or natural-resource-rich exceptions, and few of the poorest countries are outside of the tropics. The causes of tropical poverty are surely complex, involving initial endowments (Diamond), history, especially colonization, and geographical isolation (Gallup and Sachs 1999a). Central to the tropical poverty trap, though, is the impact of climate on productivity through the channels of tropical disease ecology and agriculture. This paper investigates the last channel: the causes of lower agricultural productivity in the tropics.

The disparity in agricultural productivity between the tropics and the temperate zones is even greater than the disparity in income levels (figure 1). Income per capita in nontropical countries was 3.3 times the level of income per capita in tropical countries in 1995, but agricultural output per worker in the non-tropical countries was 8.8 times the level in the tropics. ${ }^{1}$

One would expect that the productivity of agricultural labor in poor tropical countries would be lower whether or not tropical climate or soils had an impact on agriculture. In poor countries, all labor has low wages so that a lot of labor is used in agriculture relative to other factors of production, ensuring low labor productivity in agriculture. Is poverty (due to other causes) rather

\footnotetext{
John Luke Gallup is a research fellow and Jeffrey D. Sachs is director at the Harvard Center for International Development.

${ }^{1}$ Note that since the dependency ratio is higher in the lowincome tropics, the disparity in agricultural output per agricultural population is even greater. These ratios are calculated from data for 128 countries on agricultural output per farm worker using data from FAO and GDP per capita using Penn World Tables (Summers and Heston) updated to 1995 using purchasing power parity GDP growth rates from World Bank. Countries are classified as tropical if more than half the land area of the country is in the geographical tropics, shown in figure 1.
}

than agricultural conditions responsible for low agricultural productivity in the tropics? Apparently not. When controlling for income level, labor productivity in tropical agriculture is still only $51 \%$ of labor productivity in non-tropical agriculture. ${ }^{2}$

Another way to look at the agricultural fecundity of the tropics is to compare crop yields, or the output per cultivated land area. The geographical tropics is a convenient classification for describing basic patterns, but it is the not the most appropriate way to distinguish zones of agro-ecological conditions. Much better are ecozone maps based on climatic data: temperature and precipitation. From detailed Köppen ecozones, one can distinguish four broad regions: Temperate, Tropical (the humid subset of the geographical tropics), Dry (most of the rest of the geographical tropics and the very dry nontropical areas), and Cold (including high altitude areas). ${ }^{3}$

Agricultural yields for all major crop categories are lower in the tropics (table 1). The yields of six crop groups (wheat, maize, rice, pulses, root crops, and vegetables) and two livestock categories (beef and pig) are generally lowest in Tropical ecozones, slightly higher in Dry ecozones, and substantially higher in Temperate and Cold ecozones. In 1998, all of the Tropical and Dry crop yields are lower than all the Temperate and Cold ecozones except for wheat yields in the

\footnotetext{
${ }^{2}$ The regression using 1995 data with $t$-statistics in parentheses below the coefficients is

$\ln ($ ag output/worker $)=\underset{(0.18)}{-0.13}+\underset{(12.12)}{0.98^{*}} \ln ($ GDP per capita $)$ $-0.67^{*}(\%$ land area in tropics $)$ (3.44)$$
N=128 \quad R^{2}=0.77 \text {. }
$$

${ }^{3}$ The data on Köppen ecozones were digitized from Strahler and Strahler (pp. 156-57).
} 


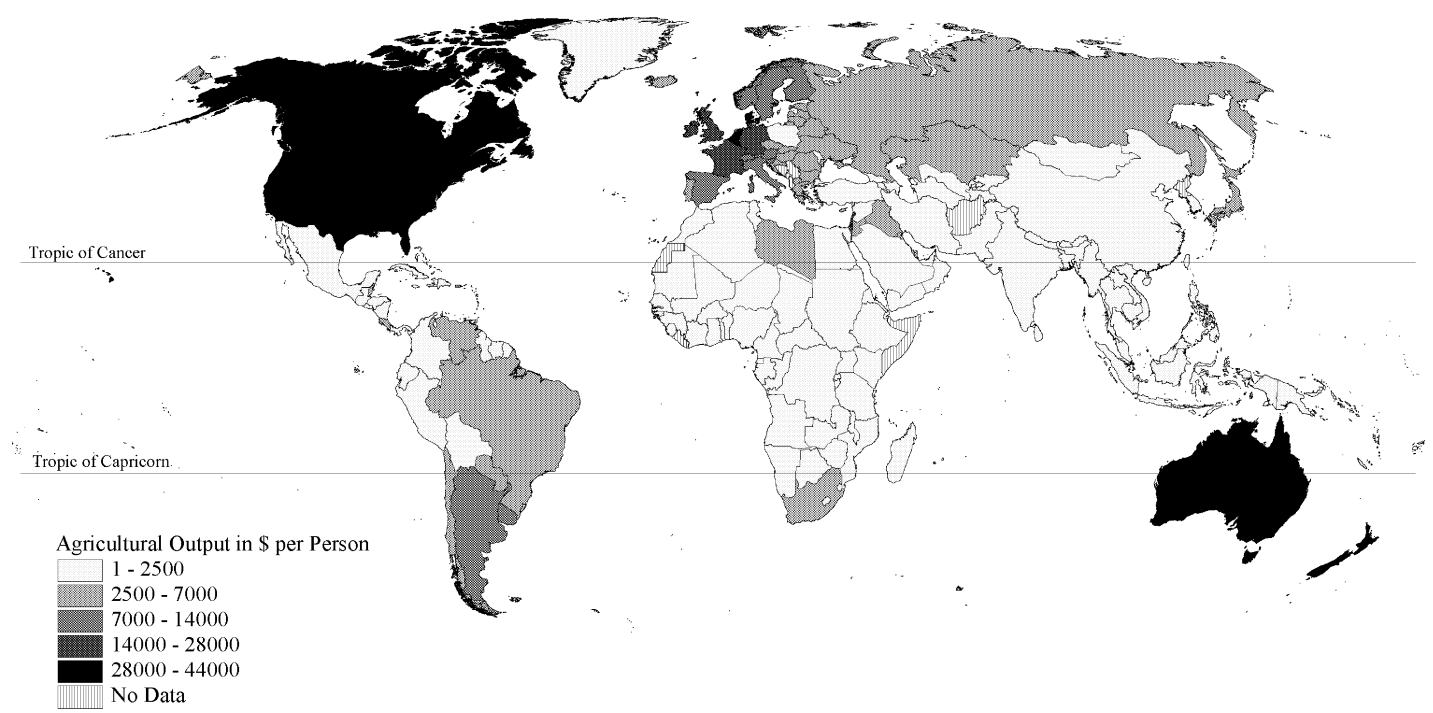

Figure 1. Agricultural output per farmworker (1994)

Dry zone. Tropical ecozone crop yields range from $36 \%$ to $67 \%$ of Temperate zone yields, while Tropical livestock yields are about three quarters of Temperate zone yields.

Comparing crop yields in 1998 with yields in 1961 shows that the tropical disparity has actually gotten worse over the past four decades for all crops except for rice. Tropical ecozone crop yields in 1961 ranged from $48 \%$ to $77 \%$ of Temperate yields (excluding rice), while livestock yields ranges from $86 \%$ to $97 \%$ (table 1). Comparing recent yields to those in 1961 also shows how much improvement there has been in crop yields everywhere. Foodgrain yields in particular have roughly doubled. Although the Tropical yields are further behind Temperate yields in 1998 than they were in 1961, Tropical yields in 1998 are near the level of Temperate yields in 1961 and surpass them in the case of cereals, wheat, and beef. Growth of cereals yields has been over $1 \%$ percent per year in the Tropical ecozones since 1961, and over $0.5 \%$ per year for the other crops.

Agricultural productivity of both labor and land are lower in the tropics, in the case of labor productivity, even after controlling for income levels. A more satisfactory way of examining the differences in agricultural productivity, though, is to take into account the whole range of inputs used in agriculture, which affect both labor and land productivities. This is done after considering several causal explanations for lower agricultural productivity in the tropics.

\section{Why Should the Tropics Be Less Conducive to Agriculture?}

The image of the humid tropics is the most fecund of environments, teeming with life. It is true that the humid tropics are teeming with biodiversity, but the conditions for biodiversity need not be related to conditions for optimal plant-growth. In many contexts biodiversity is negatively correlated with the fertility of the land [such as tree species diversity in Costa Rica (Huston, p. 514)]. Humid tropical forests are biologically productive [though often less than temperate forests [Huston, pp. 550-552]], but when the tree cover is stripped off and the land is farmed by conventional methods, it quickly loses its productivity.

Food plants are a small and particular subset of plants that need not be well suited to tropical conditions. According to Pingali (pp. 209-10), "In general, a system of farming that closely mimics the dense natural vegetation of the humid forests will work in the long run .... The humid and subhumid tropics are well suited to perennial crops such as bananas and to tree crops such as rubber, cocoa, and palm oil." None of these crops, with the possible exception of the banana, is a staple food crop.

Most explanations of the deficiencies of the humid tropics for agriculture focus on the soils (Weischet and Caviedes, Huston, and articles in Vosti and Reardon). Typical humid tropical soils (alfisols, oxisols, and ultisols) are low in nutrients and organic matter and 


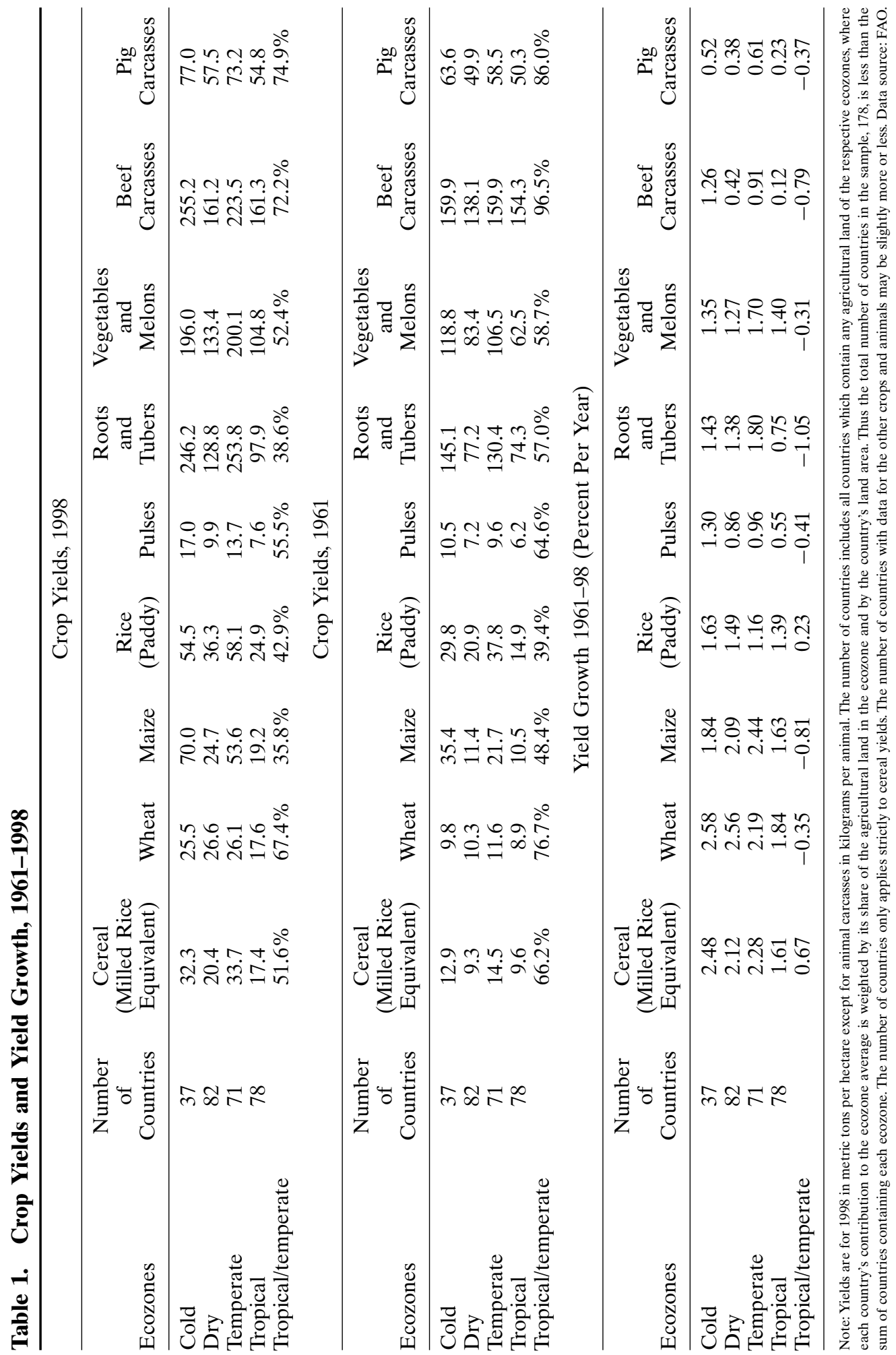


are susceptible to erosion and acidification. In addition, application of synthetic fertilizers to improve the fertility of these soils is often ineffective and unsustainable, damaging the soil structure. The deficiencies of humid tropical soils are largely due to the long term effects of the tropical climate. High temperature and humidity cause organic matter in the soil to break down quickly, robbing the soil of nutrients as well as the structure needed to absorb fertilizers and slow erosion. High intensity rainstorms in humid tropical areas cause erosion, soil leaching, and compaction.

The rapid decomposition of organic matter makes soil fertility, a major investment of farmers, depreciate more quickly in the humid tropics. Hence the rates of return to farmer investments in soil are systematically lower in the humid tropics.

Humid tropical climates cover only a part of the geographical tropics. Much of the rest of the geographical tropics is made up of arid climates, with yields typically as low or lower than humid tropical yields. According to Weischet and Caviedes, the arid tropics have few problems with soil fertility, but cannot increase yields substantially without irrigation because of the high variability of rainfall and droughts. Irrigation, they argue, is limited by the general flatness of river valleys in the semi-arid tropics, so that irrigation dams must be impractically wide.

Most explanations of the geographical limitations of agriculture in the tropics focus on problematic soils in humid tropics, and rainfall variability and limited irrigation potential in the arid topics. Additional factors explaining lower agricultural potential in the tropics are pest and disease loads, and net photosynthetic potential differences.

The lack of freezing temperatures in the tropics causes a much greater number of agricultural pests in the tropics, including veterinary diseases like trypanosomiasis. Human tropical diseases such as malaria reduce agricultural labor productivity.

Although the tropics are generally warmer and sunnier throughout the year than temperate zones, the climate has disadvantages for photosynthesis. The humid tropics are often cloudy, blocking sunlight, and the high nighttime temperatures cause high respiration that slows plant growth. During the summer months, temperate zones have longer days than the tropics, giving an advantage to summer-season crops.
In light of the recent rapid change in agricultural yields in both the tropics and non-tropics, a differential role of agricultural technology across the two zones must also be considered. Empirical research to distinguish between these reasons for the tropical disadvantage in agriculture is scarce.

\section{Quantification of the Tropical Disadvantage}

Not only do many individual crop categories have higher yields per hectare in temperate climates, as seen above, but aggregate agricultural output per hectare is about twice the level in the Temperate zone as it is in the Tropical, Dry, and Cold zones (table 2). The FAO has created a price-weighted aggregate of all agricultural output, as well as collecting country-specific data on inputs to agriculture. Like output, the main inputs used in agriculture vary widely by climatic zone. Tropical zones use four times the labor per hectare in agriculture, one-thirteenth the number of tractors, and only $40 \%$ of the fertilizer. With varying levels of inputs, it is difficult to know if the tropical deficit is due to differences in ecology or simply differences in input levels.

A more satisfactory way of isolating the impact of tropical climate and soil conditions on agriculture is to estimate an agricultural production function that controls for the use of various agricultural inputs. Using a physical production function approach avoids most of the complications of the effect of the economic policy regime on agriculture, like exchange rates, quotas, price subsidies, and taxes. Nor should missing markets affect the estimation to a first approximation. Whatever input levels are chosen, which will be affected by prices distortions and market imperfections, those inputs should have a consistent impact on output if the aggregate production function specification is tenable. Price distortions should not affect the estimated relationship between inputs applied and the output harvested.

In Gallup and Sachs (1999b) we estimate a cross-country Cobb-Douglas agricultural production, correlating aggregate agricultural output per hectare with inputs per hectare of agricultural labor, education (as a measure of labor quality), agricultural capital (proxied by 
Table 2. Agriculture Outputs, Inputs, and Income Levels by Ecozone

\begin{tabular}{lcccccc}
\hline Agricultural & $\begin{array}{c}\text { Agricultural } \\
\text { Labor per } \\
\text { Hectare }\end{array}$ & $\begin{array}{c}\text { Tractors } \\
\text { per 1,000 } \\
\text { Hectare }\end{array}$ & $\begin{array}{c}\text { Fertilizer } \\
\text { per } \\
\text { Hectare }\end{array}$ & $\begin{array}{c}\text { GDP per } \\
\text { Person, } \\
1994\end{array}$ & $\begin{array}{c}\text { Gerson Growth } \\
1965-94 \\
(\%)\end{array}$ \\
\hline Temperate & 500 & 0.10 & 24.8 & 57.9 & 11,315 & 2.1 \\
Cold & 251 & 0.20 & 12.9 & 43.6 & 11,334 & 2.3 \\
Dry & 206 & 0.30 & 2.5 & 23.2 & 5,274 & 1.3 \\
Tropical & 247 & 0.40 & 1.9 & 23 & 2,925 & 1.3 \\
\hline
\end{tabular}

Data sources: FAO, and for GDP, Penn World Tables (Summers and Heston) updated with purchasing power parity GDP growth rates from World Bank (1998). GDP is purchasing power parity using 1985 prices.

tractors and livestock), fertilizer; an indicator of the national level of technology (proxied by lagged GDP per person); an indicator of world technology level (a time trend); and shares of the agricultural land in Tropical, Dry, and Cold climates (with Temperate climate the left-out category). Data are available from 104 countries over the period 1961-94 for most countries.

Countries with Tropical and Dry climates all have significantly lower agricultural yields controlling for input and technology levels. The Tropical zones have $27 \%$ lower total factor productivity and the Dry zones have $42 \%$ lower productivity with respect to the Temperate regions. The higher productivity in the (moist) Tropical climatic zone is no comfort for the geographical tropics, though, because more of the geographical tropics are made up of Dry climatic zones $(50.4 \%)$ than Tropical climatic zones $(33.6 \%)$.

Yields of all crop categories in table 1 have been rising since the 1960s, but generally have been rising much slower in the Tropical zones. Just as with the static yield differences across climatic zones, the yield growth changes could be due all or in part to differential changes in agricultural input use. Total factor productivity shows even more dramatic differences across climatic zones than simple crop yields. Controlling for inputs, Temperate zone productivity has risen by $1.1 \%$ per year from 1961 to 1994 , but Tropical zone productivity fell by $0.6 \%$ per year and Dry zone productivity fell more by $1.0 \%{ }^{4}$ The tropics failed to keep up with the productivity growth of the rest of the world, and in fact slipped back.

\footnotetext{
${ }^{4}$ This regression does not include lagged GDP per capita as a covariate to avoid confounding trends in national GDP and total factor productivity.
}

\section{Geographical Destiny or Technology Conditioned by Geography?}

At the least, the tropics present a difficult environment for intensive cultivation of major staple crops. The potential of an given farm or locality depends on the precise microclimate, soils, water availability, crops grown, etc., which vary widely within the tropics and the nontropics, but the broad patterns are clear. Farmers typically face less fertile soils, low fertilizer efficiency, and more agricultural pests in the humid tropics, and must cope with variable rainfall or invest in irrigation in the dry tropics. A major exception to tropical problems in agriculture has been the development of high-yielding varieties of lowland rice in Asia, but recent improvements appear to have stalled out (Pingali). In a recent volume assessing the policies required to improve agriculture in various tropical agroecological zones, authors proposing solutions for four of the eleven zones included "develop non-agricultural employment" as a major recommendation (Vosti and Reardon). The prospects for productively absorbing new labor into agriculture in these zones are not good.

Despite the challenges to tropical agriculture, crop yields have grown in the tropics, even if not always sufficiently fast to best population growth. All of the crop yields in table 1 grew on average by over $1 \%$ per year except of pulses, roots, and tubers, which grew over $0.5 \%$ per year. The dynamism of agricultural yields suggests that the causes of the tropical agricultural deficit are to be found as much in different rates of agricultural improvement over time as in static disadvantages.

Tropical agriculture faces major limitations on transferring agricultural technol- 
Table 3. Public Sector Agricultural Research Expenditures 1981-85

\begin{tabular}{lcccc}
\hline Ecozones & $\begin{array}{c}\text { Research expenditures/ } \\
\text { Agricultural GDP } \\
\text { (per Billion) }\end{array}$ & $\begin{array}{c}\text { Number of } \\
\text { Countries }\end{array}$ & $\begin{array}{c}\text { Research expenditures/ } \\
\text { Agricultural Laborer } \\
(1,000 \text { 1980 PPP \$) }\end{array}$ & $\begin{array}{c}\text { Number of } \\
\text { Countries }\end{array}$ \\
\hline Temperate & 18.0 & 22 & 231.2 & 30 \\
Cold & 36.9 & 6 & 511.3 & 7 \\
Dry & 8.9 & 29 & 12.9 & 34 \\
Tropical & 11.2 & 46 & 11.7 & 52 \\
Total & 16.0 & 103 & 147.4 & 123 \\
\hline
\end{tabular}

Source: Pardey, Roseboom, and Anderson; World Bank (1998); FAO; and authors' calculations.

ogy developed for the richer temperatecountry markets to tropical climatic zones. Whereas innovations in machinery can be used interchangeably throughout the world, new crop varieties must be painstakingly adapted to each new ecological zone due to agriculture's dependence on local climate and soils.

Agricultural research is heavily concentrated outside of the tropics. Counting only public-sector agricultural research, $73 \%$ is performed in countries that have predominantly Temperate and Cold climates (calculated from Pardey, Roseboom, and Anderson). Privatesector agricultural research spending, which now dwarfs public research funding, is almost exclusively directed at Temperate and Cold climate zones because of their high income markets, so that worldwide public and private agriculture research is very heavily skewed toward the non-tropics. The research and development budget of the entire CGIAR system of institutes studying developing world agricultural problems is less than half of the R\&D budget of one life-sciences multinational, Monsanto (Sachs, p. 19).

The Tropical and Dry climatic zones lag by almost any measure of agricultural research. In terms of public expenditures on agricultural research in 1981-85, the Dry and Tropical zones invested approximately half as much per dollar of agricultural output as Temperate zone countries (table 3 ). The differences in research expenditure per agricultural laborer are gargantuan: Temperate countries spend nineteen times as much on research per laborer as Tropical and Dry zone countries. Whereas many interventions in developing country agriculture, such as irrigation projects and rural development schemes, have had poor results, agricultural research provides strikingly high rates of return. Of 161 studies surveyed in table 4 , the average rate of return was $54.7 \%$. The highest rates of return are found in Tropical zone countries with a mean return of $63.4 \%$ and the tenth percentile return at $23.0 \%$. These high rates of return imply serious underinvestment in agricultural research, especially in the tropics.

The large disparities in agricultural productivity between the regions of the world have worrying implications for agricultural development, especially in the tropics. Our estimates suggest that tropical agricultural output is at least one-third lower than the temperate regions when applying the same inputs. This is a huge disadvantage, and throws into question the viability of an "agriculture-led" development strategy in the mostly agricultural tropics.

The near-term welfare of more than half the households in most tropical countries (69\% of the labor force of low-income economies on average in 1990 according to World Bank 1997, p. 20), and an even higher proportion of the poor, still depends on agriculture. Few countries can sustainably import their food staples. Sixty-five of 167 countries in the U.N. population projections are expected to have population growth over $1.5 \%$ per year over the 2000-40 period. Populations in most of these countries will double over this period. All of these countries have the majority of their population living in Dry or Tropical ecozones.

\section{References}

Diamond, J. Guns, Germs, and Steel: The Fates of Human Societies. New York: W. W. Norton, 1997.

Echeverría, R.G. "Assessing the Impact of Agricultural Research." Methods for Diagnosing Research System Constraints and Assessing the 
Table 4. Rates of Return to Agricultural Research

\begin{tabular}{lcccc}
\hline Ecozones & Mean & Median & Tenth Percentile & Number of Countries \\
\hline Temperate & 55.4 & 40.5 & 20.0 & 84 \\
Cold & 56.8 & 51.0 & 22.0 & 13 \\
Dry & 39.0 & 37.5 & 18.0 & 26 \\
Tropical & 63.4 & 53.5 & 23.0 & 38 \\
Total & 54.7 & 43.0 & 20.0 & 161 \\
\hline
\end{tabular}

Source: Echevarría and authors' calculations.

Impact of Agricultural Research-Volume II, Assessing the Impact of Agricultural Research. R. G. Echeverría, ed., pp. 1-31. The Hague: ISNAR, 1990.

FAO. FAOStat Database, 1994. http://apps.fao.org/ default.htm

Gallup, J.L., and J.D. Sachs. "Geography and Economic Development." World Bank Annual Conference on Development Economics 1998. Boris Pleskovic and Joseph E. Stiglitz, eds., pp. 127-178. Washington DC: The World Bank, 1999a.

. "Agricultural Productivity and the Tropics." Unpublished, Harvard Center for International Development, 1999b.

Huston, M.A. Biological Diversity: The Coexistence of Species on Changing Landscapes. Cambridge UK: Cambridge University Press, 1994.

Pardey, P.G., J. Roseboom, and J.R. Anderson. "Appendix." Agricultural Research Policy: International Quantitative Perspectives. pp. 413-21. Cambridge UK: Cambridge University Press for ISNAR, 1991.

Pingali, P.L. "Agriculture-Environment-Poverty Interactions in the Southeast Asian Humid
Tropics." Sustainability, Growth and Poverty Alleviation: A Policy and Agroecological Perspective. Stephen A. Vosti and Thomas Reardon, eds., pp. 208-28. Baltimore MD: Johns Hopkins University Press, 1997.

Sachs, J. "Helping the World's Poorest." The Economist 352(14 August 1999):17-20.

Strahler, A.H., and A.N. Strahler. Modern Physical Geography. Fourth Edition. New York: John Wiley and Sons, 1992.

Summers, R., and A. Heston. The Penn World Tables, Mark 5.6, 1994. http://www.nber.org/ pwt56.html

Vosti, S.A., and T. Reardon, eds. Sustainability, Growth and Poverty Alleviation: A Policy and Agroecological Perspective. Baltimore MD: Johns Hopkins University Press, 1997.

Weischet, W., and C.N. Caviedes. The Persisting Ecological Constraints of Tropical Agriculture. New York: Longman Scientific and Technical, 1993.

World Bank. World Development Report. Washington DC: World Bank, 1997.

- World Development Indicators 1998, CD-ROM. Washington DC: World Bank, 1998. 